\title{
Topologically and geometrically flexible structural units in seven new organically templated uranyl selenates and selenite-selenates
}

\author{
Vladislav V. Gurzhiy ${ }^{a, *}$, Vadim M. Kovrugin ${ }^{a}$, Olga S. Tyumentseva ${ }^{a}$, \\ Pavel A. Mikhaylenko ${ }^{a}$, Sergey V. Krivovichev ${ }^{a}$, Ivan G. Tananaev ${ }^{\mathrm{b}}$ \\ a Department of Crystallography, St. Petersburg State University, University Emb. 7/9, 199034 St. Petersburg, Russia \\ ${ }^{\mathrm{b}}$ National Research Nuclear University MEPhI, pr. Pobedy 48, 456783 Ozersk, Russia
}

\section{A R T I C L E I N F O}

\section{Article history:}

Received 6 March 2015

Received in revised form

24 April 2015

Accepted 27 April 2015

Available online 8 May 2015

\section{Keywords:}

Uranyl

Selenate

Crystal structure

Topology

Isomerism

X-ray diffraction

\begin{abstract}
A B S T R A C T
Single crystals of seven novel uranyl oxysalts of selenium with protonated methylamine molecules, $\left[\mathrm{C}_{2} \mathrm{H}_{8} \mathrm{~N}\right]_{2}\left[\left(\mathrm{UO}_{2}\right)\left(\mathrm{SeO}_{4}\right)_{2}\left(\mathrm{H}_{2} \mathrm{O}\right)\right](\mathbf{I}),\left[\mathrm{C}_{2} \mathrm{H}_{8} \mathrm{~N}\right]_{2}\left[\left(\mathrm{UO}_{2}\right)_{2}\left(\mathrm{SeO}_{4}\right)_{3}\left(\mathrm{H}_{2} \mathrm{O}\right)\right](\mathbf{I I}),\left[\mathrm{C}_{4} \mathrm{H}_{15} \mathrm{~N}_{3}\right]\left[\mathrm{H}_{3} \mathrm{O}\right]_{0.5}\left[\left(\mathrm{UO}_{2}\right)_{2}\left(\mathrm{SeO}_{4}\right)_{2.93}(-\right.$ $\left.\left.\mathrm{SeO}_{3}\right)_{0.07}\left(\mathrm{H}_{2} \mathrm{O}\right)\right]\left(\mathrm{NO}_{3}\right)_{0.5} \quad(\mathbf{I I I}), \quad\left[\mathrm{C}_{2} \mathrm{H}_{8} \mathrm{~N}_{3}\left[\mathrm{H}_{5} \mathrm{O}_{2}\right]\left[\left(\mathrm{UO}_{2}\right)_{2}\left(\mathrm{SeO}_{4}\right)_{3}\left(\mathrm{H}_{2} \mathrm{O}\right)_{2}\right]_{2}\left(\mathrm{H}_{2} \mathrm{O}\right)_{5} \quad(\mathbf{I V}), \quad\left[\mathrm{C}_{2} \mathrm{H}_{8} \mathrm{~N}\right]_{2}\left[\mathrm{H}_{3} \mathrm{O}\right]\left[\left(\mathrm{UO}_{2}\right)_{3}\right.\right.$ $\left.\left(\mathrm{SeO}_{4}\right)_{4}\left(\mathrm{HSeO}_{3}\right)\left(\mathrm{H}_{2} \mathrm{O}\right)\right]\left(\mathrm{H}_{2} \mathrm{SeO}_{3}\right)_{0.2}(\mathbf{V}), \quad\left[\mathrm{C}_{4} \mathrm{H}_{12} \mathrm{~N}\right]_{3}\left[\mathrm{H}_{3} \mathrm{O}\right]\left[\left(\mathrm{UO}_{2}\right)_{3}\left(\mathrm{SeO}_{4}\right)_{5}\left(\mathrm{H}_{2} \mathrm{O}\right)\right](\mathbf{V I})$, and $\left[\mathrm{C}_{2} \mathrm{H}_{8} \mathrm{~N}\right]_{3}\left(\mathrm{C}_{2} \mathrm{H}_{7} \mathrm{~N}\right)$ $\left[\left(\mathrm{UO}_{2}\right)_{3}\left(\mathrm{SeO}_{4}\right)_{4}\left(\mathrm{HSeO}_{3}\right)\left(\mathrm{H}_{2} \mathrm{O}\right)\right](\mathbf{V I I})$ have been prepared by isothermal evaporation from aqueous solutions. Their crystal structures have been solved by direct methods and their uranyl selenate and selenite-selenate units investigated using black-and-white graphs from the viewpoints of topology of interpolyhedral linkages and isomeric variations. The crystal structure of IV is based upon complex layers with unique topology, which has not been observed previously in uranyl selenates. Investigations of the statistics and local distribution of the $\mathrm{U}-\mathrm{O}_{\mathrm{br}}-\mathrm{Se}$ bond angles demonstrates that shorter angles associate with undulations, whereas larger angles correspond to planar areas of the uranyl selenite layers.
\end{abstract}

(c) 2015 Elsevier Inc. All rights reserved.

\section{Introduction}

Within the last decade actinide oxysalts attracted significant attention due to their importance in mineralogy, uranium mining technologies and studies related to the advanced nuclear fuel cycle. The diversity of polyhedral units found in uranyl compounds is unique, starting from isolated complexes [1-3] and clusters [4-7] to cage compounds [8-11] and nanotubules [12-14]. Selenium-containing uranyl oxysalts are known for both monoand divalent inorganic cations [15-19], as well as for organic template molecules of various charge and structure [20-24]. The crystal structures of uranyl selenates and selenites are based upon a variety of complex units formed by polymerization of $U$ and Se coordination polyhedra. The topology and geometry of these units is controlled by a number of factors, governing interactions between organic and inorganic substructures. The principles that describe these interactions include hydrophillic-hydrophobic interactions, charge-density matching and weak hydrogen bonding that nevertheless may induce distortions of particular geometries of U-O-Se links. Herein we report on the syntheses and structural characterization of seven novel Se-contaning uranyl

\footnotetext{
* Corresponding author. Tel.: + 79119749592.

E-mail addresses: vladgeo17@mail.ru (V.V. Gurzhiy), vladgeo17@mail.ru (I.G. Tananaev).
}

oxysalts that contain protonated organic molecules as interlayer species.

\section{Experimental}

\subsection{Synthesis}

$\mathrm{N}, \mathrm{N}$-dimethylformamide (99\%, Sigma-Aldrich), dimethylamine (40 wt\% in $\mathrm{H}_{2} \mathrm{O}$, Aldrich), diethylenetriamine (99\%, Sigma-Aldrich), diethylamine (99\%, Sigma-Aldrich), selenic acid (40 wt\% in $\mathrm{H}_{2} \mathrm{O}$, 99.95\%, Aldrich), and $\mathrm{UO}_{2}\left(\mathrm{NO}_{3}\right)_{2} \cdot 6 \mathrm{H}_{2} \mathrm{O}$ (Vekton) were used as received. $\left[\mathrm{C}_{2} \mathrm{H}_{8} \mathrm{~N}\right]_{2}\left[\left(\mathrm{UO}_{2}\right)\left(\mathrm{SeO}_{4}\right)_{2}\left(\mathrm{H}_{2} \mathrm{O}\right)\right] \quad(\mathbf{I}), \quad\left[\mathrm{C}_{2} \mathrm{H}_{8} \mathrm{~N}\right]_{2}\left[\left(\mathrm{UO}_{2}\right)_{2}(-\right.$ $\left.\left.\mathrm{SeO}_{4}\right)_{3}\left(\mathrm{H}_{2} \mathrm{O}\right)\right] \quad(\mathrm{II}), \quad\left[\mathrm{C}_{4} \mathrm{H}_{15} \mathrm{~N}_{3}\right]\left[\mathrm{H}_{3} \mathrm{O}\right]_{0.5}\left[\left(\mathrm{UO}_{2}\right)_{2}\left(\mathrm{SeO}_{4}\right)_{2.93}\left(\mathrm{SeO}_{3}\right)_{0.07}\right.$ $\left.\left(\mathrm{H}_{2} \mathrm{O}\right)\right]\left(\mathrm{NO}_{3}\right)_{0.5}(\mathrm{III}),\left[\mathrm{C}_{2} \mathrm{H}_{8} \mathrm{~N}\right]_{3}\left[\mathrm{H}_{5} \mathrm{O}_{2}\right]\left[\left(\mathrm{UO}_{2}\right)_{2}\left(\mathrm{SeO}_{4}\right)_{3}\left(\mathrm{H}_{2} \mathrm{O}\right)_{2}\right]_{2}\left(\mathrm{H}_{2} \mathrm{O}\right)_{5}$ (IV), $\left[\mathrm{C}_{2} \mathrm{H}_{8} \mathrm{~N}\right]_{2}\left[\mathrm{H}_{3} \mathrm{O}\right]\left[\left(\mathrm{UO}_{2}\right)_{3}\left(\mathrm{SeO}_{4}\right)_{4}\left(\mathrm{HSeO}_{3}\right)\left(\mathrm{H}_{2} \mathrm{O}\right)\right]\left(\mathrm{H}_{2} \mathrm{SeO}_{3}\right)_{0.2}(\mathbf{V})$, $\left[\mathrm{C}_{4} \mathrm{H}_{12} \mathrm{~N}\right]_{3}\left[\mathrm{H}_{3} \mathrm{O}\right]\left[\left(\mathrm{UO}_{2}\right)_{3}\left(\mathrm{SeO}_{4}\right)_{5}\left(\mathrm{H}_{2} \mathrm{O}\right)\right](\mathbf{V I})$, and $\left[\mathrm{C}_{2} \mathrm{H}_{8} \mathrm{~N}\right]_{3}\left(\mathrm{C}_{2} \mathrm{H}_{7} \mathrm{~N}\right)$ $\left[\left(\mathrm{UO}_{2}\right)_{3}\left(\mathrm{SeO}_{4}\right)_{4}\left(\mathrm{HSeO}_{3}\right)\left(\mathrm{H}_{2} \mathrm{O}\right)\right]$ (VII) have been prepared by evaporation from aqueous solutions of uranyl nitrate, $40 \%$-solution of selenic acid, $N, N$-dimethylformamide, $40 \%$-solution of methylamine, diethylenetriamine, diethylamine, and deionized distilled water. Yellow-green homogeneous liquid solutions were left in a fumehood at the room temperature. The crystals of compound I, and II were synthesized through the reaction $0.198 \mathrm{~g}(0.4 \mathrm{mmol})$ of uranyl nitrate, $0.094 \mathrm{~g}(1.3 \mathrm{mmol})$ of $\mathrm{N}, \mathrm{N}$-dimethylformamide, 
$0.590 \mathrm{~g}$ ( $4.1 \mathrm{mmol})$ of selenic acid and $2.001 \mathrm{~g}(110.2 \mathrm{mmol})$ of deionized distilled water. The crystals of compound IV, and $\mathbf{V}$ were synthesized through the reaction $0.0502 \mathrm{~g}(0.1 \mathrm{mmol})$ of uranyl nitrate, $0.009 \mathrm{~g}(0.2 \mathrm{mmol})$ of dimethylamine, $0.102 \mathrm{~g}(0.7 \mathrm{mmol})$ of selenic acid and $2.002 \mathrm{~g}$ (110.2 mmol) of deionized distilled water. The crystals of compound VII were synthesized through the reaction $0.0502 \mathrm{~g}(0.1 \mathrm{mmol})$ of uranyl nitrate, $0.018 \mathrm{~g}(0.4 \mathrm{mmol})$ of dimethylamine, $0.072 \mathrm{~g}(0.5 \mathrm{mmol})$ of selenic acid and $2.001 \mathrm{~g}$ $(110.2 \mathrm{mmol})$ of deionized distilled water. The crystals of compound III were synthesized through the reaction $0.100 \mathrm{~g}$ $(0.2 \mathrm{mmol})$ of uranyl nitrate, $0.010 \mathrm{~g}(0.1 \mathrm{mmol})$ of diethylenetriamine, $0.102 \mathrm{~g}$ ( $0.7 \mathrm{mmol})$ of selenic acid and $2.002 \mathrm{~g}$ (110.2 mmol) of deionized distilled water. The crystals of compound VI were synthesized through the reaction $0.059 \mathrm{~g}(0.1 \mathrm{mmol})$ of uranyl nitrate, $0.010 \mathrm{~g}(0.1 \mathrm{mmol})$ of diethylamine, $0.679 \mathrm{~g}(4.7 \mathrm{mmol})$ of selenic acid and $2.002 \mathrm{~g}$ ( $110.2 \mathrm{mmol})$ of deionized distilled water. The solid products were formed after three days in small amount. The $\mathrm{pH}$ values of the solutions described above are in the range from 1 to 0 , moreover for the newly prepared solutions the values tend closer to 1 , whereas precipitation of crystals increases acidity.

\subsection{Single crystal X-ray study}

Single crystals of I-VII have been selected for data collection under an optical microscope, encased in epoxy and mounted on glass fibres. Data were collected using monochromatic MoK $\alpha$ radiation $(\lambda[\mathrm{MoK} \alpha]=$ $0.71073 \AA$ ) by means of a Bruker SMART APEX II CCD (I-VI) and STOE IPDS II (VII) diffractometers. The unit-cell parameters were refined by least-squares techniques. Data were integrated and corrected for background, Lorentz, and polarization effects using an empirical spherical model by means of the Bruker programs APEX2 and XPREP (I-VI) and STOE X-AREA (VII). Absorption correction was applied using the SADABS program [25] for (I-VI) and STOE X-RED \& X-SHAPE [26] for VII. The structures were solved by direct methods and refined using the SIR-92 [27] and SHELXL-97 programs [28] incorporated in the OLEX2 program package [29]. Due to the low quality of crystals (especially phases IV-VII), their metastability and sensitivity to air, only rather rough structural models could be obtained, which is manifested in the presence of high residual electron-density peaks, low bond precision, and refinement of organic molecules in isotropic approximation only (VII), as well as in the impossibility to localize the positions of several $\mathrm{H}$ atoms. However, the hydrogen bonding system in such cases can be inferred from the short O-O contacts involving sites occupied by water and hydronium molecules. The final models included coordinates and anisotropic displacement parameters for all non-hydrogen atoms. The carbon-bound $\mathrm{H}$ atoms were placed in calculated positions and were included in the refinement in the 'riding' model approximation, with $\mathrm{U}_{i s o}(\mathrm{H})$ set to $1.5 \mathrm{U}_{e q}(\mathrm{C})$ and $\mathrm{C}-\mathrm{H}$ $0.96 \AA$ for $\mathrm{CH}_{3}$ groups, with $\mathrm{U}_{\text {iso }}(\mathrm{H})$ set to $1.2 \mathrm{U}_{e q}(\mathrm{C})$ and $\mathrm{C}-\mathrm{H} 0.97 \AA$ for $\mathrm{CH}_{2}$ groups, $\mathrm{U}_{\text {iso }}(\mathrm{H})$ set to $1.2 \mathrm{U}_{e q}(\mathrm{~N})$ and $\mathrm{N}-\mathrm{H} 0.89 \AA$ for the $\mathrm{NH}_{3}$ groups, and $\mathrm{U}_{\text {iso }}(\mathrm{H})$ set to $1.2 \mathrm{U}_{e q}(\mathrm{~N})$ and $\mathrm{N}-\mathrm{H} 0.86 \AA$ for the $\mathrm{NH}_{2}$ groups. Positions of $\mathrm{H}$ atoms of $\mathrm{H}_{2} \mathrm{O}$ molecules, hydronium cations and $\mathrm{OH}^{-}$groups were localized from difference Fourier maps and kept fixed during refinement. Relevant crystallographic data are listed in Table 1. Selected interatomic distances are listed in Tables S1-S7. CCDC files 901940, 901941, 901942, 901943, 901944, 901945, and 901946 contain the supplementary crystallographic data for the compounds I-VII, respectively. These data can be obtained free of charge from The Cambridge Crystallographic Data Centre via www.ccdc.cam.ac.uk/ data_request/cif

\section{Results}

\subsection{Structural descriptions}

The crystal structures of all seven compounds reported in this paper contain uranyl pentagonal bipyramids and selenate tetrahedra. The structures of $\mathbf{V}$ and $\mathbf{V I I}$ also contain selenite trigonal pyramids. The polyhedra are linked into inorganic structural units. The structures contain one (I), two (II, III, V, VI and VII), or four (IV) crystallographically unique $\mathrm{U}^{\mathrm{VI}}$ cations forming approximately linear uranyl ions, $\left[\mathrm{UO}_{2}\right]^{2+}$, with the $\mathrm{U}=\mathrm{O}$ bond lengths varying from 1.711 (10) $\AA$ to 1.787(7) $\AA$. These basic uranyl entities are coordinated in their equatorial planes by four oxygen atoms and one $\mathrm{H}_{2} \mathrm{O}$ molecule to form $\mathrm{UO}_{7}$ pentagonal bipyramids with the average $\left\langle\mathrm{U}-\mathrm{O}_{e q}\right\rangle$ bond lengths equal to $2.390 \AA$. The $\mathrm{U}-\mathrm{H}_{2} \mathrm{O}$ bond lengths lie in range of $2.424(12)-2.554(7) \AA$. In the structure of I there are two symmetrically independent $\mathrm{Se}^{\mathrm{VI}}$ atoms. The structures of II, III, IV, and VI contain three $\mathrm{Se}^{\mathrm{VI}}$ atoms each, whereas the structure of IV contains six

Table 1

Crystallographic data for I, II, III, IV, V, VI and VII.

\begin{tabular}{|c|c|c|c|c|c|c|c|}
\hline Compound & I & II & III & IV & $\mathbf{V}$ & VI & VII \\
\hline Formula mass & 666.15 & 1079.14 & 2256.03 & 2267.28 & 1685.05 & 1770.70 & 1685.07 \\
\hline Space group & $P 2_{1} 2_{1} 2_{1}$ & $P 2_{1} 2_{1} 2_{1}$ & $P 2_{1} / c$ & $P 2_{1} / c$ & $P 2_{1} / m$ & $P 2_{1} / m$ & Pnma \\
\hline$a(\AA)$ & $7.5363(7)$ & $11.2154(5)$ & $11.1679(4)$ & $12.451(5)$ & $8.3116(4)$ & $8.941(2)$ & 11.6591(11) \\
\hline$b(\AA)$ & $12.2021(11)$ & $11.2263(5)$ & $10.9040(4)$ & $31.126(5)$ & $18.6363(8)$ & $19.300(4)$ & $14.9556(17)$ \\
\hline$c(\AA)$ & $16.7601(16)$ & $16.9138(8)$ & $17.9913(6)$ & $14.197(4)$ & $11.5623(5)$ & $11.377(3)$ & $22.194(2)$ \\
\hline$\beta\left({ }^{\circ}\right)$ & 90.00 & 90.00 & $98.019(1)$ & $120.39(2)$ & $97.582(1)$ & $97.510(4)$ & 90.00 \\
\hline$V\left(\AA^{3}\right)$ & $1541.2(2)$ & $2129.57(17)$ & $2169.57(17)$ & $4746(2)$ & $1775.31(14)$ & $1946.5(7)$ & $3870.0(7)$ \\
\hline Size $\left(\mathrm{mm}^{3}\right)$ & $0.21 \times 0.17 \times 0.09$ & $0.21 \times 0.17 \times 0.07$ & $0.23 \times 0.19 \times 0.08$ & $0.23 \times 0.18 \times 0.07$ & $0.19 \times 0.14 \times 0.08$ & $0.22 \times 0.20 \times 0.06$ & $0.26 \times 0.20 \times 0.09$ \\
\hline$\mu\left(\mathrm{mm}^{-1}\right)$ & 15.306 & 20.394 & 20.036 & 18.323 & 19.286 & 17.217 & 17.310 \\
\hline$Z$ & 4 & 4 & 2 & 4 & 2 & 2 & 4 \\
\hline $2 \theta$ range $\left({ }^{\circ}\right)$ & $4.13-60.00$ & $4.35-60.00$ & $4.38-55.00$ & $2.62-55.00$ & $4.17-60.00$ & $4.18-54.98$ & $3.28-39.10$ \\
\hline$D_{\text {calc }}\left(\mathrm{g} / \mathrm{cm}^{3}\right)$ & 2.871 & 3.366 & 3.457 & 3.173 & 3.152 & 3.021 & 2.892 \\
\hline Total ref. & 13,644 & 17,184 & 23,671 & 34,682 & 23,753 & 18,435 & 10,911 \\
\hline Unique ref. & 4492 & 6112 & 4988 & 10896 & 5323 & 4597 & 1680 \\
\hline Unique $\left|F_{o}\right| \geq 4 \sigma_{F}$ & 4117 & 5340 & 3855 & 5379 & 3940 & 2459 & 1221 \\
\hline$R_{\text {int }}$ & 0.0564 & 0.0651 & 0.0723 & 0.0963 & 0.0762 & 0.1196 & 0.1116 \\
\hline$R_{\sigma}$ & 0.0562 & 0.0684 & 0.0574 & 0.0993 & 0.0605 & 0.1609 & 0.0714 \\
\hline$R_{1}\left(\left|F_{o}\right| \geq 4 \sigma_{F}\right)$ & 0.0311 & 0.0283 & 0.0330 & 0.0482 & 0.0362 & 0.0396 & 0.0602 \\
\hline$w R_{2}\left(\left|F_{o}\right| \geq 4 \sigma_{F}\right)$ & 0.0629 & 0.0484 & 0.0735 & 0.1060 & 0.0935 & 0.0583 & 0.0962 \\
\hline GOF & 0.940 & 0.934 & 0.964 & 0.875 & 1.083 & 0.737 & 1.127 \\
\hline$\rho_{\min }, \rho_{\min }, e\left(\AA^{3}\right)$ & $-1.497,2.339$ & $-1.199,1.099$ & $-1.997,2.824$ & $-4.340,4.608$ & $-2.216,2.793$ & $-1.383,1.651$ & $-1.210,1.054$ \\
\hline CCDC & 901940 & 901941 & 901942 & 901943 & 901944 & 901945 & 901946 \\
\hline
\end{tabular}

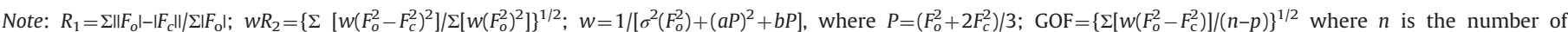
reflections and $p$ is the number of refined parameters. 
independent $\mathrm{Se}^{\mathrm{VI}}$ atoms. In the structures of $\mathbf{V}$ and $\mathbf{V I I}$ there are three independent Se positions of which two sites [Se1 and Se2] correspond to $\mathrm{Se}^{\mathrm{VI}}$, whereas the Se3 site is occupied by $\mathrm{Se}^{\mathrm{IV}}$. The $\mathrm{Se}^{\mathrm{VI}}$ cations in each structure are tetrahedrally coordinated by four $\mathrm{O}$ atoms, forming $\left[\mathrm{SeO}_{4}\right]^{2-}$ tetrahedra with the average $\langle\mathrm{Se}-\mathrm{O}\rangle$ bond length equals to $1.634 \AA$. In the structure of $\mathbf{V}$ and VII, the Se 3 site has a trigonal pyramidal coordination with an apex occupied by the $\mathrm{Se}^{\mathrm{IV}}$ atom. This coordination type is typical for $\mathrm{Se}^{\mathrm{IV}}$ cations possessing stereoactive lone electron pairs. In the structure of III, the Se3 site is occupied by both $\mathrm{Se}^{\mathrm{VI}}$ (site-occupation factor (s.o.f.) $=0.93$ ) and $\mathrm{Se}^{\mathrm{IV}}$ (s.o.f. $=0.07$ ) atoms with the total s.o.f. equal to 1.0 . The $\mathrm{Se}_{3} \mathrm{O}_{3}$ trigonal pyramids in V and VII are strongly distorted: two short equivalent bonds [1.645(6) $\AA$ And 1.653(16) $\AA$ in $\mathbf{V}$ and VII, respectively] and one longer bond [1.78 (2) $\AA$ and 1.78(4) Å in V and VII, respectively]. The observed elongation is the result of relatively strong hydrogen bonding to the nearby terminal methyl cations of the protonated dimethylamine molecule in the structure of $\mathbf{V}$, and by protonation of the selenite group in the structure of VII. The asymmetric $\left[\mathrm{SeO}_{3}\right]^{2-}$ and $\left[\mathrm{HSeO}_{3}\right]^{2-}$ selenite groups were observed, in particular, in the structures of $\left(\mathrm{NH}_{4}\right)$ $\left[\mathrm{UO}_{2}\left(\mathrm{HSeO}_{3}\right)\left(\mathrm{SeO}_{3}\right)\right][30], M\left[\left(\mathrm{UO}_{2}\right)\left(\mathrm{HSeO}_{3}\right)\left(\mathrm{SeO}_{3}\right)\right](M=\mathrm{K}, \mathrm{Rb}, \mathrm{Cs}, \mathrm{Tl})$ [31], $\left[\mathrm{C}_{5} \mathrm{H}_{14} \mathrm{~N}\right]\left[\left(\mathrm{UO}_{2}\right)\left(\mathrm{SeO}_{4}\right)\left(\mathrm{SeO}_{2} \mathrm{OH}\right)\right]$ [32], and $\left[\mathrm{C}_{5} \mathrm{H}_{14} \mathrm{~N}\right]_{4}\left(\mathrm{UO}_{2}\right)_{3}(-$ $\left.\mathrm{SeO}_{4}\right)_{4}\left(\mathrm{HSeO}_{3}\right)\left(\mathrm{H}_{2} \mathrm{O}\right)\left(\mathrm{H}_{2} \mathrm{SeO}_{3}\right)\left(\mathrm{HSeO}_{4}\right)[33]$.

In the crystal structure of $\mathbf{I}$, the $\left[\mathrm{UO}_{6}\left(\mathrm{H}_{2} \mathrm{O}\right)\right]^{6-}$ pentagonal bipyramids share corners with two adjacent $\left[\mathrm{SeO}_{4}\right]^{2-}$ tetrahedra to form $\left[\left(\mathrm{UO}_{2}\right)\left(\mathrm{SeO}_{4}\right)_{2}\left(\mathrm{H}_{2} \mathrm{O}\right)\right]^{2-}$ chains running parallel to the $b$ axis. The chains are arranged into the pseudo layers parallel to the $\left(\begin{array}{llll}0 & 0 & 1\end{array}\right)$ plane

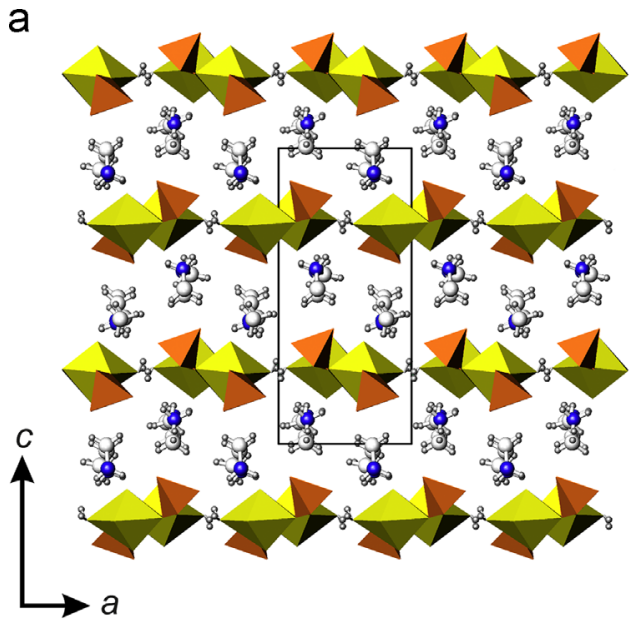

b

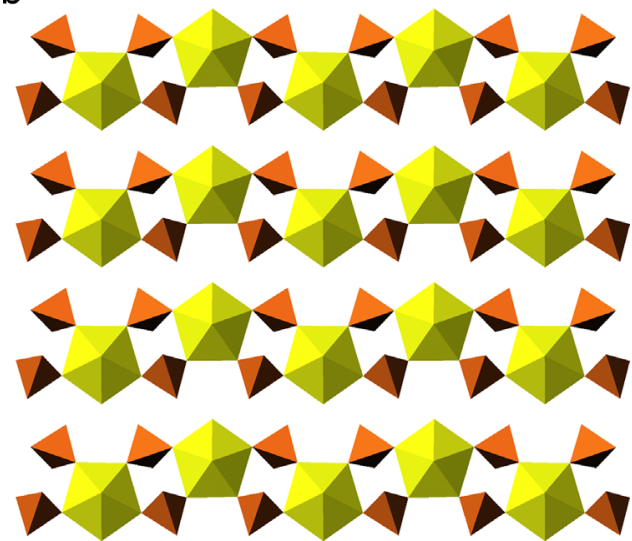

Fig. 1. The crystal structure of $\mathbf{I}$ projected along the $b$ axis (a), and the $\left[\left(\mathrm{UO}_{2}\right)\right.$ $\left.\left(\mathrm{SeO}_{4}\right)_{2}\left(\mathrm{H}_{2} \mathrm{O}\right)\right]^{2-}$ chains in the crystal structure of $\mathbf{I}(\mathbf{b})$. Legend: U polyhedra =yellow; Se polyhedra=orange; $\mathrm{C}$ and $\mathrm{N}$ atoms are white and blue, respectively; hydrogen atoms are small grey circles. (For interpretation of the references to color in this figure legend, the reader is referred to the web version of this article.)
(Fig. 1a). Two protonated dimethylamine cations $\left[\mathrm{C}_{2} \mathrm{H}_{8} \mathrm{~N}\right]^{+}$are arranged between the chains and provide their linkage into a threedimensional structure.

The crystal structures of II, IV and III, are based upon complex 2D layers with the composition $\left[\left(\mathrm{UO}_{2}\right)_{2}\left(\mathrm{SeO}_{4}\right)_{3}\left(\mathrm{H}_{2} \mathrm{O}\right)_{n}\right]^{2-}$. The topology of the $\mathrm{U}$ and Se polyhedral linkage is different for the different values of $n$. The layers are parallel to $\left(\begin{array}{lll}0 & 0 & 1\end{array}\right)$ in II and III, and to $\left(\begin{array}{lll}0 & 1 & 0\end{array}\right)$ in IV (Figs. 2 and 3). The uranyl selenate layers present in II and III are slightly corrugated. The interpolyhedral $\mathrm{U}-\mathrm{O}_{\mathrm{br}}-\mathrm{Se}$ angles in II, III and IV have the average values of $135.6^{\circ}, 136.1^{\circ}$ and $135.6 \times$, respectively, which are in general agreement with the average value of $136.8^{\circ}$ reported in [34]. The structure of II contains two protonated linear dimethylamine molecules $\left[\mathrm{C}_{2} \mathrm{H}_{8} \mathrm{~N}\right]^{+}$as interlayer species. Diprotonated diethylenetriamine cation $\left[\mathrm{C}_{4} \mathrm{H}_{15} \mathrm{~N}_{3}\right]^{2+}$, hydronium cation $\left[\mathrm{H}_{3} \mathrm{O}\right]^{+}$and disordered nitrate group $\left[\mathrm{NO}_{3}\right]^{-}$are arranged between the layers in the structure of III. In the interlayer space of IV, there are three crystallographically independent protonated $\left[\mathrm{C}_{2} \mathrm{H}_{8} \mathrm{~N}\right]^{+}$cations, one Zundel $\left[\mathrm{H}_{5} \mathrm{O}_{2}\right]^{+}$cation, and five water molecules.

The crystal structures of $\mathbf{V}, \mathbf{V I}$, and $\mathbf{V I I}$ are based upon the layers with $\mathrm{U}: \mathrm{Se}=3: 5$ formed as a result of condensation of the $\left[\mathrm{UO}_{2}\right]^{2+}$, $\left[\mathrm{UO}_{2}\left(\mathrm{H}_{2} \mathrm{O}\right)\right]^{2+},\left[\mathrm{Se}^{\mathrm{VI}} \mathrm{O}_{4}\right]^{2-},\left[\mathrm{Se}^{\mathrm{IV}} \mathrm{O}_{3}\right]^{2-}$ and $\left[\mathrm{HSe}^{\mathrm{IV}} \mathrm{O}_{3}\right]^{-}$coordination polyhedra by sharing common oxygen atoms. In the structures of $\mathbf{V}$

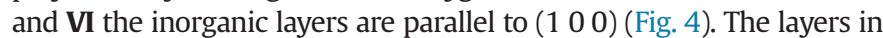
VII are parallel to $\left(\begin{array}{lll}0 & 0 & 1\end{array}\right)$ and are strongly undulated along the $c$ axis (Fig. 5). The undulation vector is parallel to [0 10 ] and is equal to $b$ (14.956 ̊). The undulation amplitude is about $15 \AA$. The undulations in the adjacent sheets have an anti-phase character, which means that large elliptical channels are created along the $a$ axis. The structure
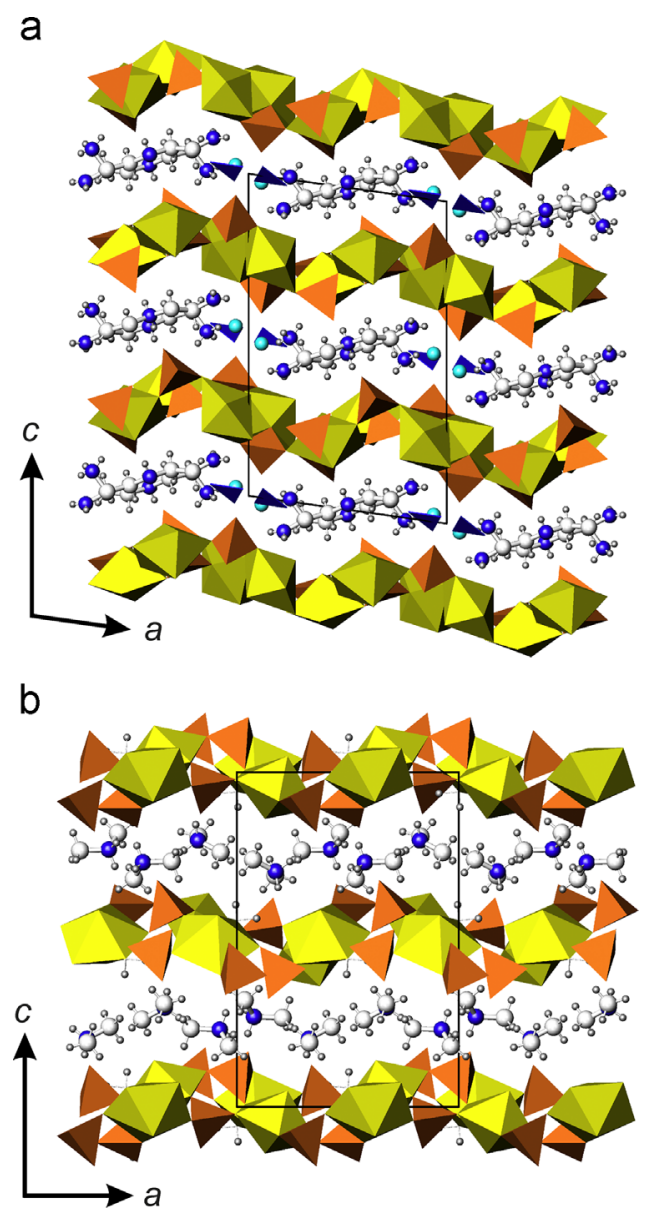

Fig. 2. The crystal structures of II and III projected along the $b$ axis, (a) and (b), respectively. Legend is as in Fig. $1 ;\left[\mathrm{H}_{3} \mathrm{O}\right]^{+}$groups=cyan circles, $\left[\mathrm{NO}_{3}\right]^{-}=$blue triangles. (For interpretation of the references to color in this figure legend, the reader is referred to the web version of this article.) 
with similar undulated layers was observed previously [35]. In the structure of $\mathbf{V}$, two protonated dimethylamine molecules $\left[\mathrm{C}_{2} \mathrm{H}_{8} \mathrm{~N}\right]^{+}$ and one hydronium cation $\left[\mathrm{H}_{3} \mathrm{O}\right]^{+}$are located in the interlayer space, and form hydrogen bonds to the $\mathrm{O}$ atoms of uranyl groups and selenium oxyanions. The structure of $\mathbf{V I}$ contains three protonated diethylamine molecules $\left[\mathrm{C}_{4} \mathrm{H}_{12} \mathrm{~N}\right]^{+}$and one hydronium cation $\left[\mathrm{H}_{3} \mathrm{O}\right]^{+}$as interlayer species. The charge of the inorganic layer in VII is compensated by three disordered protonated dimethylamine molecules $\left[\mathrm{C}_{2} \mathrm{H}_{8} \mathrm{~N}\right]^{+}$located in the interlayer space. It is of interest

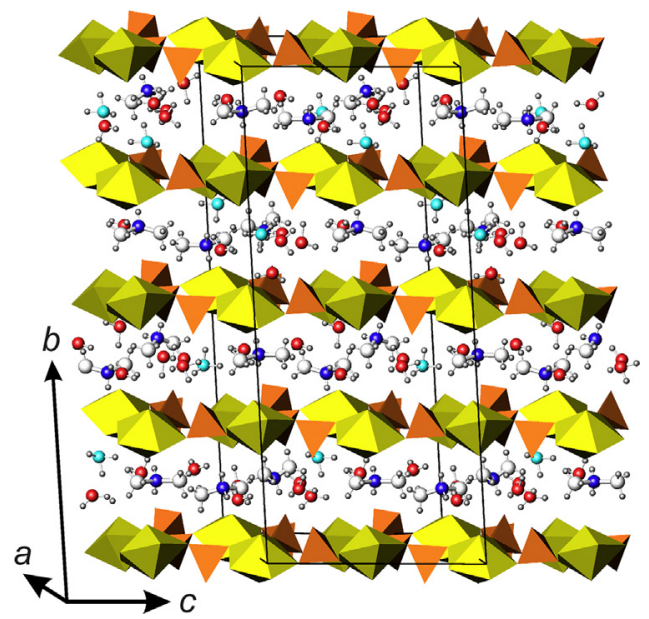

Fig. 3. The crystal structure of IV. Legend is as in Fig. $1 ;\left[\mathrm{H}_{3} \mathrm{O}\right]^{+}$groups and water molecules $=$ cyan and red circles, respectively. (For interpretation of the references to color in this figure legend, the reader is referred to the web version of this article.)
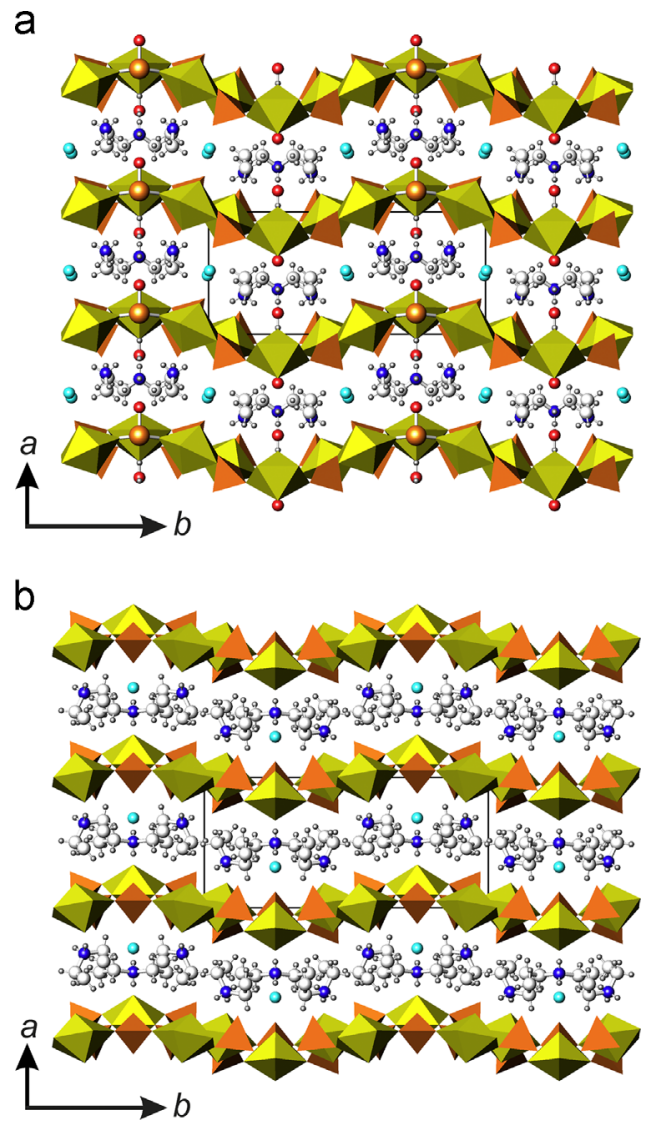

Fig. 4. The crystal structures of $\mathbf{V}$ and $\mathbf{V I}$ projected along the $b$ axis, (a) and (b) respectively. Legend is as in Fig. $1 .\left[\mathrm{H}_{3} \mathrm{O}\right]^{+}$groups and oxygen atoms=cyan and red circles; $\mathrm{Se}^{\mathrm{IV}}$ atoms = big orange circles. (For interpretation of the references to color in this figure legend, the reader is referred to the web version of this article.)

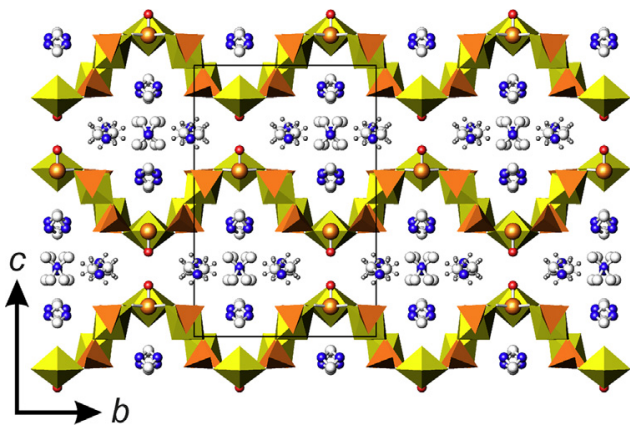

Fig. 5. The crystal structure of VII projected along the $b$ axis. Legend is as in Fig. 1; oxygen atoms $=$ circles; $\mathrm{Se}^{\mathrm{IV}}$ atoms $=$ big orange circles

that there is also one electroneutral dimethylamine molecule $\left(\mathrm{C}_{2} \mathrm{H}_{7} \mathrm{~N}\right)^{0}$ in the centre of the elliptical channels.

\subsection{Topological analysis}

Topological structure of uranyl selenate units in the structures under consideration can be visualized using the nodal representation. In the framework of this approach [36-38], the U and Se coordination polyhedra are symbolized by black and white nodes, respectively. The vertices are linked by an edge if two respective polyhedra share a common oxygen atom. The resulting graph is used to investigate topological relations between similar structures.

Fig. 1b shows the topological structure of the 1D-units of $\mathbf{I}$. The $\left[\left(\mathrm{UO}_{2}\right)\left(\mathrm{SeO}_{4}\right)_{2}\left(\mathrm{H}_{2} \mathrm{O}\right)\right]^{2-}$ chain observed in the structure of $\mathbf{I}$ corresponds to the simple 1D graph. Chains of this type are quite common for uranyl compounds with the $\left[\mathrm{TO}_{4}\right]^{n-}$ tetrahedra $(T=\mathrm{S}, \mathrm{Se}, \mathrm{P}, \mathrm{As})$. They have been observed first in the structure of $\mathrm{Mn}\left[\left(\mathrm{UO}_{2}\right)\right.$ $\left.\left(\mathrm{SO}_{4}\right)_{2}\left(\mathrm{H}_{2} \mathrm{O}\right)\right]\left(\mathrm{H}_{2} \mathrm{O}\right)_{5}$ [39] and later in a number of amine-templated uranyl sulfates [40-45] and other compounds, including $\left[\left(\mathrm{UO}_{2}\right)\right.$ $\left.\left(\mathrm{H}_{2} \mathrm{PO}_{4}\right)_{2}\left(\mathrm{H}_{2} \mathrm{O}\right)\right]\left(\mathrm{H}_{2} \mathrm{O}\right)_{2} \quad[46], \quad\left[\left(\mathrm{UO}_{2}\right)\left(\mathrm{H}_{2} \mathrm{AsO}_{4}\right)_{2}\left(\mathrm{H}_{2} \mathrm{O}\right)\right]$ [47], $\quad M\left[\left(\mathrm{UO}_{2}\right)\right.$ $\left.\left(\mathrm{SeO}_{4}\right)_{2}\left(\mathrm{H}_{2} \mathrm{O}\right)\right]\left(\mathrm{H}_{2} \mathrm{O}\right)_{4} \quad(M=\mathrm{Mg}, \quad \mathrm{Zn}) \quad[48], \quad\left[\mathrm{C}_{5} \mathrm{H}_{16} \mathrm{~N}_{2}\right]_{2}\left[\left(\mathrm{UO}_{2}\right)\left(\mathrm{SeO}_{4}\right)_{2}\right.$ $\left.\left(\mathrm{H}_{2} \mathrm{O}\right)\right]\left(\mathrm{NO}_{3}\right)_{2}$ [49], [ $\left.\mathrm{CH}_{3} \mathrm{NH}_{3}\right]_{2}\left[\left(\mathrm{UO}_{2}\right)\left(\mathrm{SeO}_{4}\right)_{2}\left(\mathrm{H}_{2} \mathrm{O}\right)\right]\left(\mathrm{H}_{2} \mathrm{O}\right)[50]$.

Fig. $6 \mathrm{a}$ and $\mathrm{b}$ shows uranyl selenate layers in the structures of II, III, and IV. The corresponding black-and-white graphs are depicted in Fig. $6 \mathrm{c}$ and d. In the crystal structure of II and III, the topology of the $\left[\left(\mathrm{UO}_{2}\right)_{2}\left(\mathrm{SeO}_{4}\right)_{3}\left(\mathrm{H}_{2} \mathrm{O}\right)_{n}\right]^{2-}$ layers with $n=1$ is based upon 4- and 6-membered rings of alternating black and white nodes. The graph has been observed in uranyl sulfates $\left[\mathrm{N}_{2} \mathrm{C}_{3} \mathrm{H}_{12}\right]$ [ $\left.\left(\mathrm{UO}_{2}\right)_{2}\left(\mathrm{H}_{2} \mathrm{O}\right)\left(\mathrm{SO}_{4}\right)_{3}\right]$ [44], $\left[\mathrm{N}_{2} \mathrm{C}_{4} \mathrm{H}_{14}\right]\left[\left(\mathrm{UO}_{2}\right)_{2}\left(\mathrm{H}_{2} \mathrm{O}\right)\left(\mathrm{SO}_{4}\right)_{3}\right]\left(\mathrm{H}_{2} \mathrm{O}\right)$ [51], and uranyl selenates $\left[\mathrm{C}_{4} \mathrm{H}_{12} \mathrm{~N}\right]_{2}\left[\left(\mathrm{UO}_{2}\right)_{2}\left(\mathrm{SeO}_{4}\right)_{3}\left(\mathrm{H}_{2} \mathrm{O}\right)\right],\left[\mathrm{C}_{4} \mathrm{H}_{14} \mathrm{~N}_{2}\right]$ $\left[\left(\mathrm{UO}_{2}\right)_{2}\left(\mathrm{SeO}_{4}\right)_{3}\left(\mathrm{H}_{2} \mathrm{O}\right)\right]\left(\mathrm{H}_{2} \mathrm{O}\right)_{2},\left[\mathrm{C}_{3} \mathrm{H}_{10} \mathrm{~N}\right]_{2}\left[\left(\mathrm{UO}_{2}\right)_{2}\left(\mathrm{SeO}_{4}\right)_{3}\left(\mathrm{H}_{2} \mathrm{O}\right)\right]\left(\mathrm{H}_{2} \mathrm{O}\right)$, $\left[\mathrm{C}_{5} \mathrm{H}_{16} \mathrm{~N}_{2}\right]\left[\left(\mathrm{UO}_{2}\right)_{2}\left(\mathrm{SeO}_{4}\right)_{3}\left(\mathrm{H}_{2} \mathrm{O}\right)\right]\left(\mathrm{H}_{2} \mathrm{O}\right)$ [52], $\mathrm{K}\left(\mathrm{H}_{5} \mathrm{O}_{2}\right)\left[\left(\mathrm{UO}_{2}\right)_{2}\left(\mathrm{SeO}_{4}\right)_{3}\right.$ $\left.\left(\mathrm{H}_{2} \mathrm{O}\right)\right]$ [53]. The topology of the $\left[\left(\mathrm{UO}_{2}\right)_{2}\left(\mathrm{SeO}_{4}\right)_{3}\left(\mathrm{H}_{2} \mathrm{O}\right)_{n}\right]^{2-}$ layer with $n=2$ in IV contains 4- and 8-membered rings. This topology is rare and has previously been observed only in two uranyl chromates $\left(\mathrm{NH}_{4}\right)_{2}\left(\mathrm{UO}_{2}\right)_{2}\left(\mathrm{CrO}_{4}\right)_{3}\left(\mathrm{H}_{2} \mathrm{O}\right)_{6}$ [54] and $\mathrm{K}_{2}\left[\left(\mathrm{UO}_{2}\right)_{2}\left(\mathrm{CrO}_{4}\right)_{3}\right.$ $\left.\left(\mathrm{H}_{2} \mathrm{O}\right)_{2}\right]\left(\mathrm{H}_{2} \mathrm{O}\right)_{4}$ [55], but has never been observed in uranyl selenates.

The crystal structures of $\mathbf{V}, \mathbf{V I}$, and $\mathbf{V I I}$ are based upon the layers with $\mathrm{U}: \mathrm{Se}=3: 5$ (Fig. 7a). These structures have the same topology of inorganic layers. The corresponding graph (Fig. 7b) is built from 4- and 6-membered rings. This topology of inorganic complexes is typical for uranyl selenite-selenates such as $\left[\mathrm{C}_{5} \mathrm{H}_{14} \mathrm{~N}\right]_{4}\left[\left(\mathrm{UO}_{2}\right)_{3}\left(\mathrm{SeO}_{4}\right)_{4}\left(\mathrm{HSeO}_{3}\right)\right.$ $\left.\left(\mathrm{H}_{2} \mathrm{O}\right)\right]\left(\mathrm{H}_{2} \mathrm{SeO}_{3}\right)\left(\mathrm{HSeO}_{4}\right)$ [33], $\left(\mathrm{H}_{3} \mathrm{O}\right)\left[\mathrm{C}_{5} \mathrm{H}_{14} \mathrm{~N}\right]_{2}\left[\left(\mathrm{UO}_{2}\right)_{3}\left(\mathrm{SeO}_{4}\right)_{4}\left(\mathrm{HSeO}_{4}\right)\right.$ $\left.\left(\mathrm{H}_{2} \mathrm{O}\right)\right],\left(\mathrm{H}_{3} \mathrm{O}\right)\left[\mathrm{C}_{5} \mathrm{H}_{14} \mathrm{~N}\right]_{2}\left[\left(\mathrm{UO}_{2}\right)_{3}\left(\mathrm{SeO}_{4}\right)_{4}\left(\mathrm{HSeO}_{4}\right)\left(\mathrm{H}_{2} \mathrm{O}\right)\right]\left(\mathrm{H}_{2} \mathrm{O}\right)$ [56], and has also been observed in some uranyl selenates: $\mathrm{Rb}_{4}\left[\left(\mathrm{UO}_{2}\right)_{3}(-\right.$ $\left.\left.\mathrm{SeO}_{4}\right)_{5}\left(\mathrm{H}_{2} \mathrm{O}\right)\right]$ [57], $\left(\mathrm{H}_{5} \mathrm{O}_{2}\right)_{2}\left(\mathrm{H}_{3} \mathrm{O}\right)_{2}\left[\left(\mathrm{C}_{10} \mathrm{H}_{20} \mathrm{O}_{5}\right)_{2}\right]\left[\left(\mathrm{UO}_{2}\right)_{3}\left(\mathrm{SeO}_{4}\right)_{5}\left(\mathrm{H}_{2} \mathrm{O}\right)\right]$ and $\left(\mathrm{H}_{5} \mathrm{O}_{2}\right)\left(\mathrm{H}_{3} \mathrm{O}\right)_{3}\left[\mathrm{C}_{10} \mathrm{H}_{20} \mathrm{O}_{5}\right]_{5}\left[\left(\mathrm{UO}_{2}\right)_{3}\left(\mathrm{SeO}_{4}\right)_{5}\left(\mathrm{H}_{2} \mathrm{O}\right)\right]$ [58]. 
a

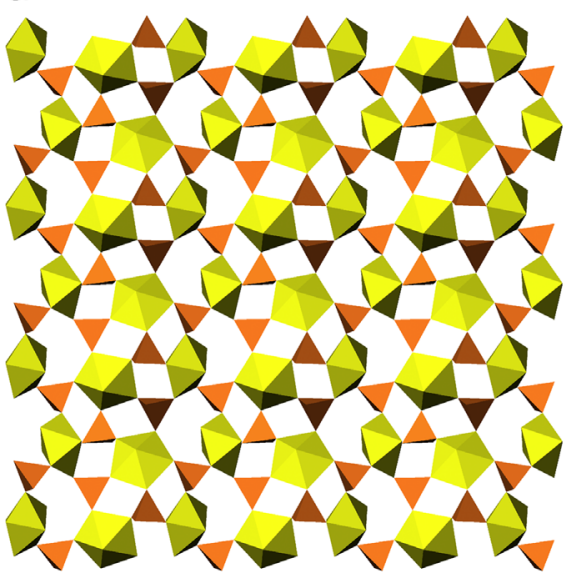

C

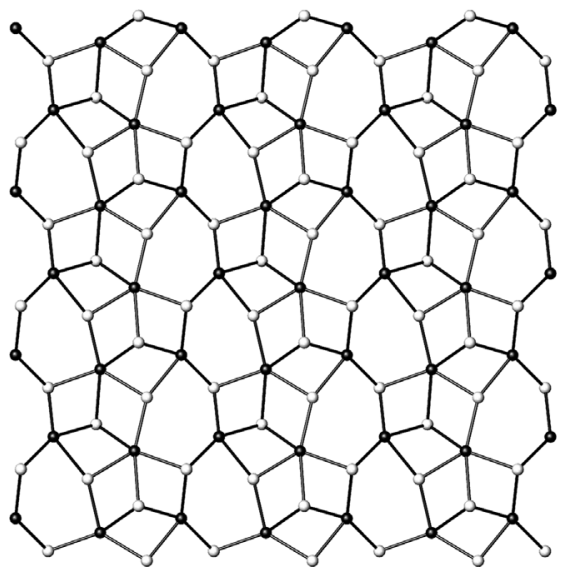

b

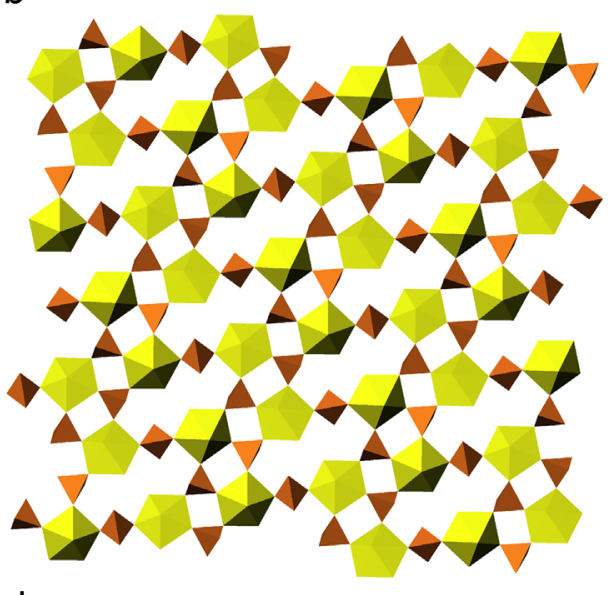

d

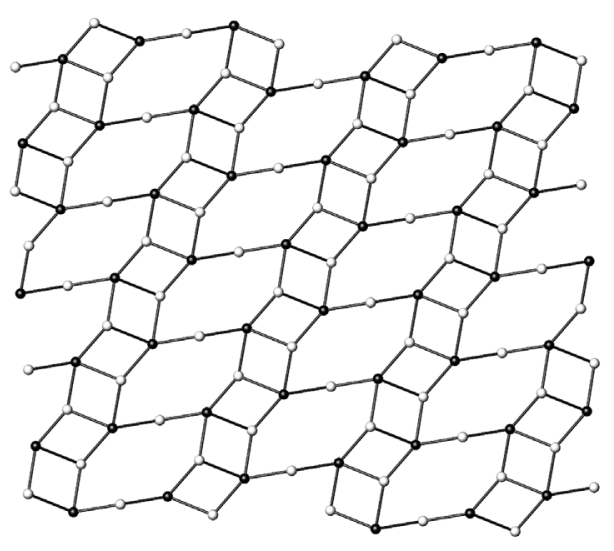

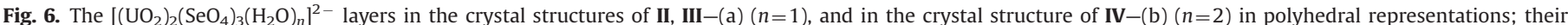
graphs ( $c$ and d, respectively). Legend is as in Fig. 1; white vertices $=$ Se, black vertices $=U$.

\subsection{Geometrical isomerism}

To define a topology of the layer by means of its nodal representation is not enough to define its complete topological structure. The detailed examination of orientations of structural units may reveal geometrical difference between the layers with the same black-and-white graph, which led Krivovichev and Burns [57] to the definition of geometrical isomerism. It is important to note that the isomers cannot be transformed one into another by simple rotations without breaking of chemical bonds. To distinguish between the layers with the same graph observed in the structures of II, III, and V, VI, VII, one has to analyse orientations of selenium polyhedra relative to the planes of the layers.

The analysis of the black-and-graph of the topology of layers of $\mathbf{V}$, VI and VII (Fig. 7d-f) indicates that its white vertices are either 2- or 3-connected: 2-connected white vertices correspond to selenite trigonal pyramids, whereas 3-connected correspond to selenate tetrahedra. These selenite-selenate polyhedra share three of its corners with adjacent 4- or 5-connected uranyl pentagonal bipyramids. The non-shared corners may have either up-, down- or disordered (up-ordown) orientations relative to the plane of the layer. This ambiguity gives rise to geometric isomers with various orientations of the selenium polyhedra. To identify and classify the isomers of this type, we use their orientation matrices [58]. According to this approach, as applied to the structures in hand, the symbols $\mathbf{u}$ (up), $\mathbf{d}$ (down), $\mathbf{m}$ (orientation up-down topologically equivalent) or $\square$ (white vertex is missing in the graph) are assigned to each white vertex.

The graphs shown in Fig. 8 have the $\mathbf{u}, \mathbf{d}$ and $\mathbf{m}$ symbols written near white vertices. It can be seen that the systems of the u, d and $\mathbf{m}$ symbols are different for the layers, which therefore should be considered as different geometrical isomers. The isomers can be distinguished by their orientation matrices that provide short notations of the translational independent rectangular system of the $\mathbf{u}, \mathbf{d}, \mathbf{m}$ and $\square$ symbols. The orientation matrices of the layers in the crystal structures of $\mathbf{V}, \mathbf{V I}$ and VII shown in Figs. $8 \mathrm{~d}-\mathrm{f}$ have $6 \times 2$ dimensions and can be written in

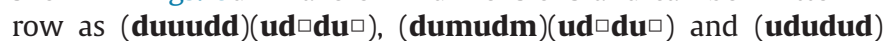
( $\mathbf{u d} \square \mathbf{d u} \square$ ), respectively. Thus, the uranyl selenite layers observed in the crystal structures of $\mathbf{V}, \mathbf{V I}$ and $\mathbf{V I I}$ correspond to different geometrical isomers.

Using the above procedure, we can constitute the equivalence of the orientation matrices of the inorganic layers of the crystal structures of II and III. The same orientation matrix for these structures may be written as (u⿺ $\square$ dd)(uu $\square$ d) (Fig. 9).

\subsection{Flexibility of structural units}

An interesting feature of the substantial number of uranyl compounds [37,59], including seven structures reported herein, is the connection of adjacent coordination polyhedra through the common bridging vertices that can be depicted as a sort of a flexible ball-insocket arrangement. This flexibility results in the relative ease of adaptation of layered $\left[\left(\mathrm{UO}_{2}\right)_{x}\left(\mathrm{TO}_{4}\right)_{y}\right]^{z-}$ systems to variable cations and other species present in the solutions during crystallization. As it has been observed in multiple experiments, there is no direct correlation between the size of the cation and the degree of the layer distortion (corrugation). The presence of large cations or molecules may lead to minor tiltings of coordination polyhedra at their connections, i.e. 


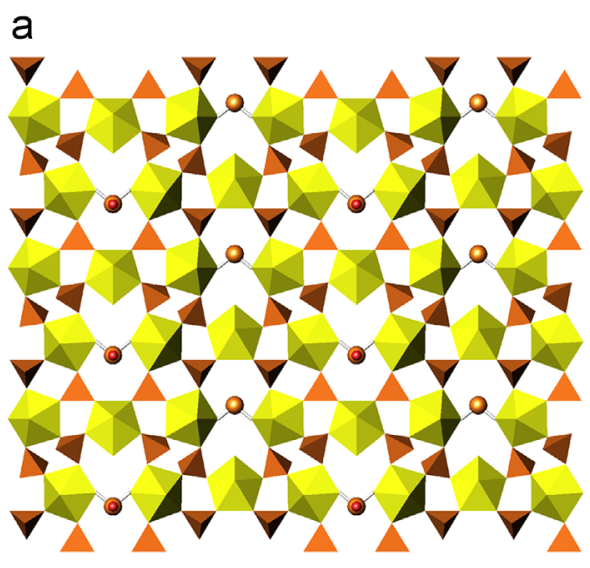

d

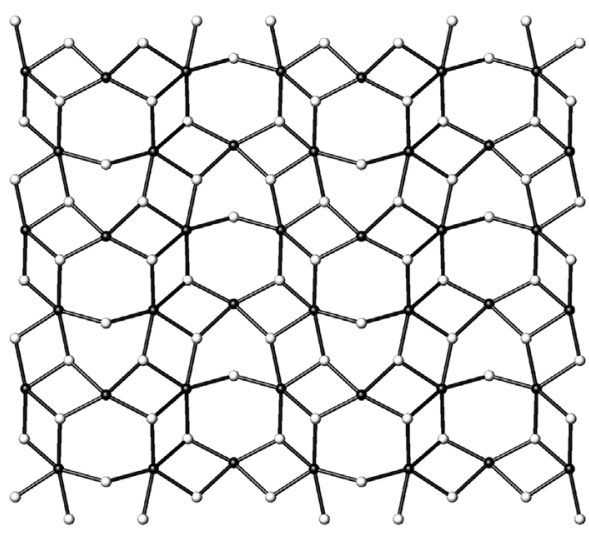

b

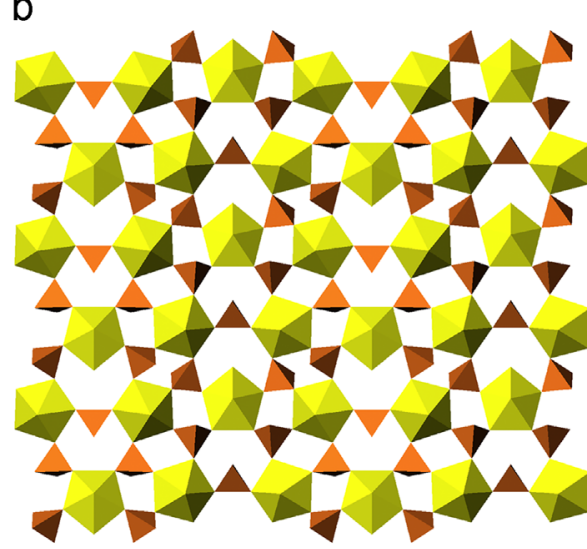

e

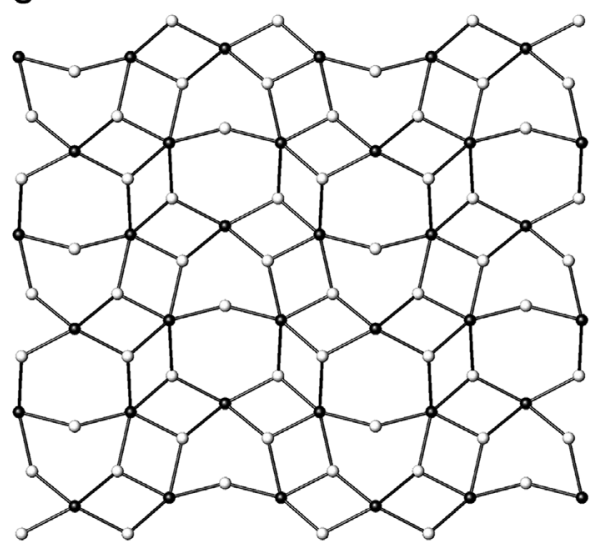

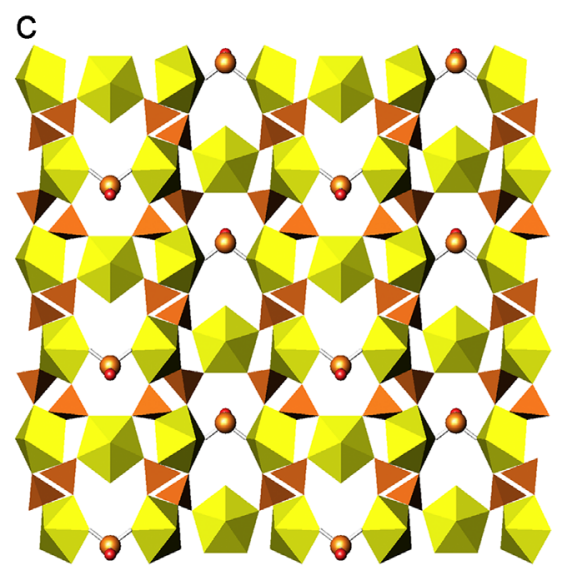

$f$

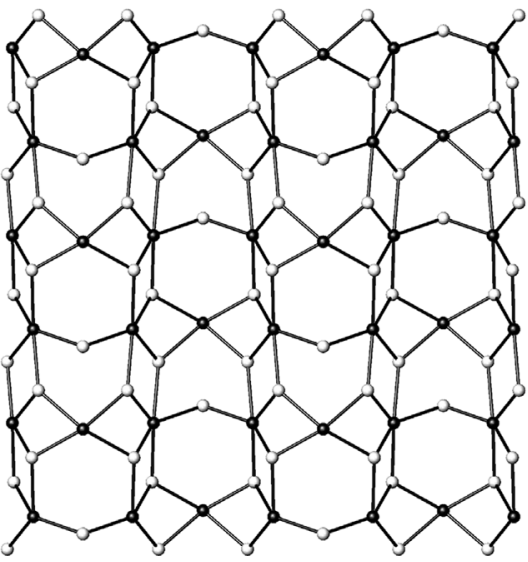

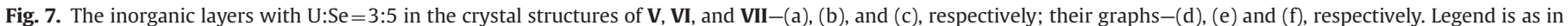
Fig. 5. See text for details.

a

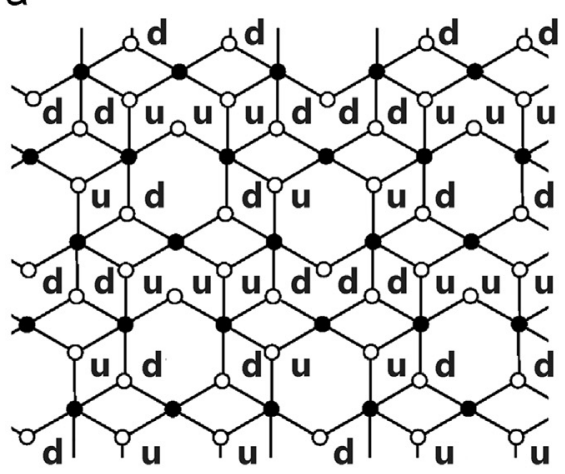

b

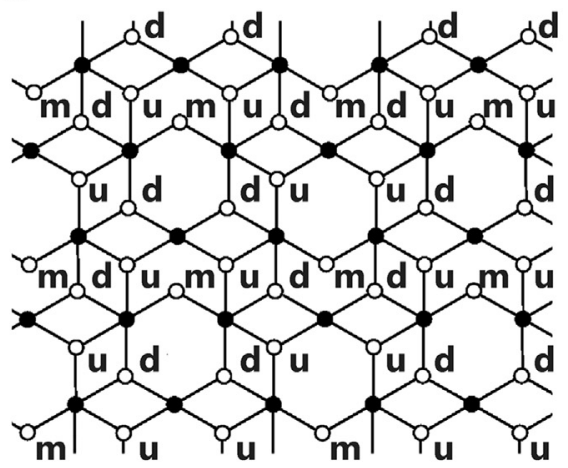

C

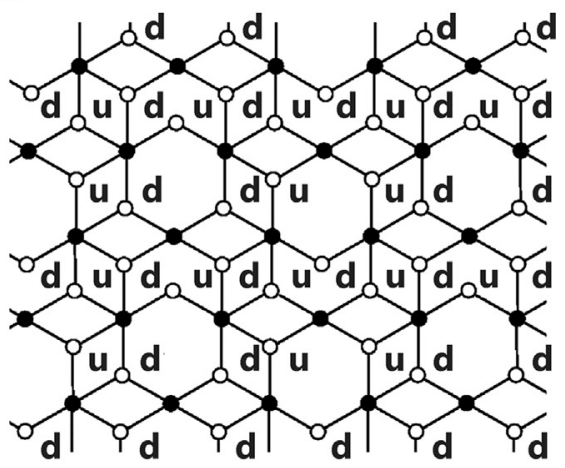

d

e

$\square$ u d $\square$ d u $\square$ u d $\square$ d d $\begin{array}{lllllllllllll}d & u & u & u & d & d & d & u & u & u\end{array}$ $\square$ u d $\square$ d u $\square$ u d $\square$ d

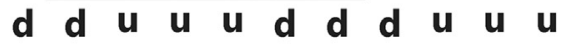
$\square$ u d $\square$ d u $\square$ u d $\square$ d

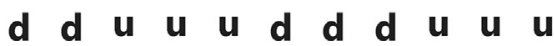

$\square$ u d $\square$ d u $\square$ u d $\square$ d

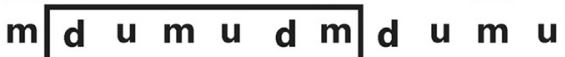
$\square$ u d $\square$ d u $\square$ u d $\square$ d $m$ d $u$ m u $d \mathbf{m}$ d $u m u$

\section{$\mathrm{f}$}

$\square$ u d $\square$ d u $\square$ u d $\square$ d d $\begin{array}{lllllllllll} & u & d & u & d & u & d & u & d & u & d\end{array}$ $\square\lfloor$ u d $\square$ d u $\square$ u d $\square$ d d $u$ d $u$ d $u$ d $u$ d $u$ d $\square$ u d $\square$ d u $\square$ u d $\square$ d

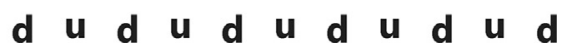

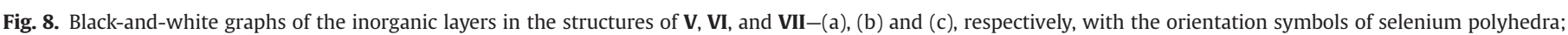
extended tables of orientation symbols (d), (e) and (f), respectively. Translational independent orientation matrices are selected in extended tables by rectangular areas.

around bridging oxygen atoms, to result in a symmetry reduction [60] compared to the ideal symmetry of structural units. In some cases, interactions between interlayer species and uranyl oxysalt units result in distortion of the layer planes and, in rare cases, formation of tubular structures [12-14]. The total effect of the 2-D unit bending includes rotation and displacements of individual $\mathrm{U}-\mathrm{O}_{\mathrm{br}}-\mathrm{T}$ fragments (Fig. 10). 
a

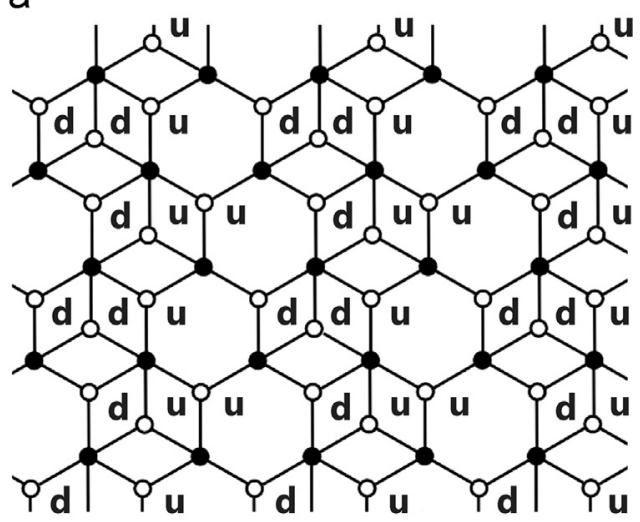

b

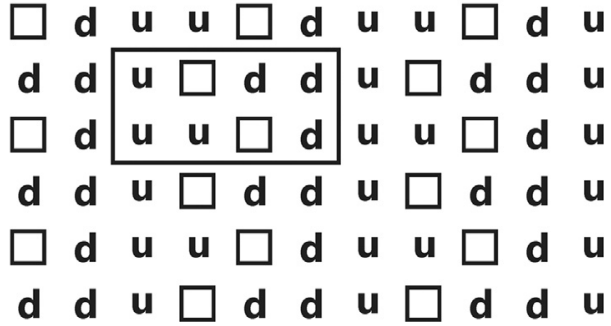

Fig. 9. Black-and-white graph of the inorganic layers in the structures of II, and III (a) with the orientation symbols of selenium polyhedra; extended tables of orientation symbols-(b). Translational independent orientation matrices are selected in (b) by rectangular areas.

a

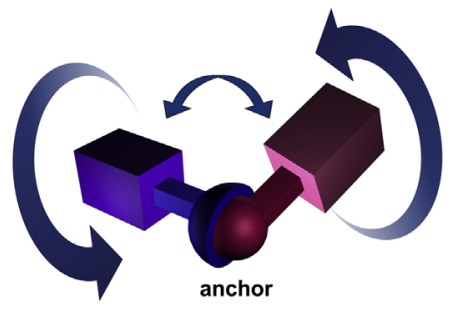

b

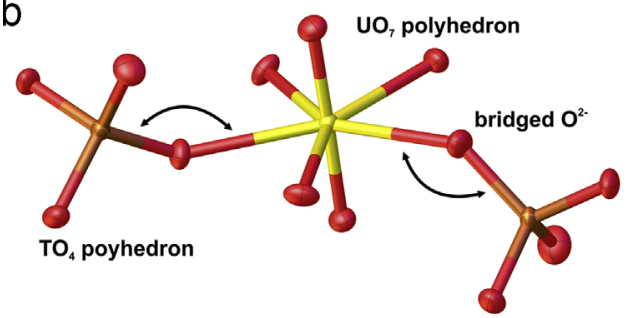

C

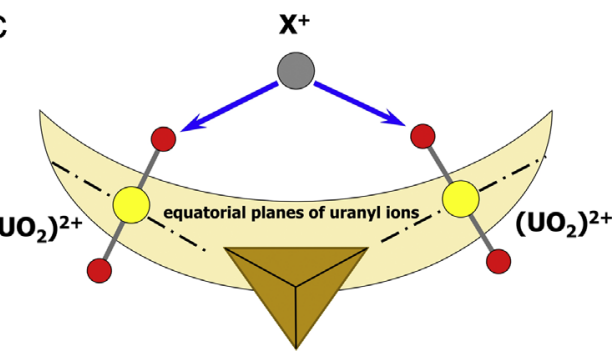

Fig. 10. Ball-in-socket joint model (a) and its working principle in the structures of uranyl containing compounds ( $\mathrm{b}$ and $\mathrm{c}$ ).

Therefore, it can be assumed that the value of the layer distortion can be determined by analyzing the bond angles at bridging oxygen atoms. This principle has a restricted application and works only locally, because of the fact that polyhedral tiltings are often occur in
Table 2

The $\mathrm{U}-\mathrm{O}_{\mathrm{br}}-$ Se bond angles $\left({ }^{\circ}\right)$ in the structures of $\mathbf{I}-\mathbf{V I I}$.

\begin{tabular}{|c|c|c|c|}
\hline I & & $\mathrm{U} 3-\mathrm{O} 4-\mathrm{Se} 4$ & $141.2(6)$ \\
\hline $\mathrm{U} 1-\mathrm{O} 3-\mathrm{Se} 1$ & $138.0(4)$ & $\mathrm{U} 3-\mathrm{O} 17-\mathrm{Se} 4$ & $132.3(6)$ \\
\hline $\mathrm{U} 1-\mathrm{O} 5-\mathrm{Se} 1$ & $137.4(4)$ & U3-O8-Se5 & $132.8(6)$ \\
\hline $\mathrm{U} 1-\mathrm{O} 7-\mathrm{Se} 2$ & $141.6(3)$ & $\mathrm{U} 3-\mathrm{O} 29-\mathrm{Se} 6$ & $135.7(6)$ \\
\hline $\mathrm{U} 1-\mathrm{O} 9-\mathrm{Se} 2$ & $137.1(4)$ & $\mathrm{U} 4-\mathrm{O} 12-\mathrm{Se} 4$ & $133.8(6)$ \\
\hline \multirow[t]{2}{*}{$\left\langle\mathrm{U}-\mathrm{O}_{\mathrm{br}}-\mathrm{Se}\right\rangle$} & 138.5 & $\mathrm{U} 4-\mathrm{O} 5-\mathrm{Se} 5$ & $132.2(6)$ \\
\hline & & $\mathrm{U} 4-\mathrm{O} 10-\mathrm{Se} 5$ & $143.2(7)$ \\
\hline II & & $\mathrm{U} 4-016-\mathrm{Se} 6$ & $134.4(6)$ \\
\hline $\mathrm{U} 1-\mathrm{O} 3-\mathrm{Se} 1$ & $134.0(4)$ & $\left\langle\mathrm{U}-\mathrm{O}_{\mathrm{br}}-\mathrm{Se}\right\rangle$ & 135.6 \\
\hline $\mathrm{U} 1-\mathrm{O} 5-\mathrm{Se} 1$ & $143.3(4)$ & & \\
\hline $\mathrm{U} 1-\mathrm{O} 8-\mathrm{Se} 2$ & $137.1(4)$ & $\mathbf{V}$ & \\
\hline $\mathrm{U} 1-\mathrm{O} 9-\mathrm{Se} 2$ & $133.8(3)$ & $\mathrm{U} 1-\mathrm{O} 1-\mathrm{Se} 1$ & $134.3(3)$ \\
\hline $\mathrm{U} 1-\mathrm{O} 16-\mathrm{Se} 3$ & $132.5(3)$ & $\mathrm{U} 1-\mathrm{O} 4-\mathrm{Se} 2$ & $141.3(4)$ \\
\hline $\mathrm{U} 2-\mathrm{O} 6-\mathrm{Se} 1$ & $128.7(4)$ & $\mathrm{U} 1-\mathrm{O} 12-\mathrm{Se} 1$ & $131.4(3)$ \\
\hline $\mathrm{U} 2-\mathrm{O} 10-\mathrm{Se} 2$ & $133.8(3)$ & $\mathrm{U} 1-\mathrm{O} 8-\mathrm{Se} 2$ & $142.9(4)$ \\
\hline $\mathrm{U} 2-\mathrm{O} 14-\mathrm{Se} 3$ & $143.6(4)$ & $\mathrm{U} 1-\mathrm{O} 9-\mathrm{Se} 3$ & $136.8(3)$ \\
\hline $\mathrm{U} 2-\mathrm{O} 15-\mathrm{Se} 3$ & $134.0(4)$ & $\mathrm{U} 2-\mathrm{O} 2-\mathrm{Se} 1$ & $142.9(3)$ \\
\hline \multirow{2}{*}{$\left\langle\mathrm{U}-\mathrm{O}_{\mathrm{br}}-\mathrm{Se}\right\rangle$} & 135.6 & $\mathrm{U} 2-\mathrm{O} 5-\mathrm{Se} 2$ & $161.0(5)$ \\
\hline & & $\left\langle\mathrm{U}-\mathrm{O}_{\mathrm{br}}-\mathrm{Se}\right\rangle$ & 141.5 \\
\hline \multicolumn{4}{|c|}{ 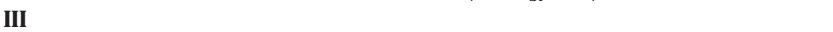 } \\
\hline $\mathrm{U} 1-\mathrm{O} 4-\mathrm{Se} 1$ & $140.9(3)$ & VI & \\
\hline $\mathrm{U} 1-\mathrm{O} 5-\mathrm{Se} 1$ & $143.6(4)$ & $\mathrm{U} 1-\mathrm{O} 4-\mathrm{Se} 1$ & $150.3(4)$ \\
\hline $\mathrm{U} 1-\mathrm{O} 6-\mathrm{Se} 2$ & $133.8(3)$ & $\mathrm{U} 1-\mathrm{O} 14-\mathrm{Se} 2$ & $136.1(4)$ \\
\hline $\mathrm{U} 1-\mathrm{O} 3-\mathrm{Se} 3$ & $132.9(3)$ & $\mathrm{U} 2-\mathrm{O} 5-\mathrm{Se} 1$ & $133.7(4)$ \\
\hline $\mathrm{U} 1-\mathrm{O} 7-\mathrm{Se} 3$ & $133.4(4)$ & $\mathrm{U} 2-\mathrm{O} 6-\mathrm{Se} 1$ & $132.7(4)$ \\
\hline $\mathrm{U} 2-\mathrm{O} 13-\mathrm{Se} 1$ & $131.2(3)$ & $\mathrm{U} 2-\mathrm{O} 10-\mathrm{Se} 2$ & $134.5(4)$ \\
\hline $\mathrm{U} 2-\mathrm{O} 10-\mathrm{Se} 2$ & $138.1(3)$ & $\mathrm{U} 2-\mathrm{O} 12-\mathrm{Se} 2$ & $153.4(4)$ \\
\hline $\mathrm{U} 2-\mathrm{O} 11-\mathrm{Se} 2$ & $136.5(3)$ & $\mathrm{U} 2-\mathrm{O} 11-\mathrm{Se} 3$ & $135.3(4)$ \\
\hline $\mathrm{U} 2-\mathrm{O} 12-\mathrm{Se} 3$ & $134.6(3)$ & $\left\langle\mathrm{U}-\mathrm{O}_{\mathrm{br}}-\mathrm{Se}\right\rangle$ & 139.4 \\
\hline \multirow[t]{2}{*}{$\left\langle\mathrm{U}-\mathrm{O}_{\mathrm{br}}-\mathrm{Se}\right\rangle$} & 136.1 & & \\
\hline & & VII & \\
\hline IV & & $\mathrm{U} 1-\mathrm{O} 9-\mathrm{Se} 1$ & $132.8(10)$ \\
\hline $\mathrm{U} 1-\mathrm{O} 7-\mathrm{Se} 1$ & $132.3(5)$ & $\mathrm{U} 1-\mathrm{O} 14-\mathrm{Se} 1$ & $132.6(13)$ \\
\hline $\mathrm{U} 1-\mathrm{O} 11-\mathrm{Se} 1$ & $133.4(6)$ & $\mathrm{U} 1-\mathrm{O} 1-\mathrm{Se} 2$ & $157.2(13)$ \\
\hline $\mathrm{U} 1-\mathrm{O} 2-\mathrm{Se} 2$ & $140.9(6)$ & $\mathrm{U} 1-\mathrm{O} 5-\mathrm{Se} 2$ & $139.4(10)$ \\
\hline $\mathrm{U} 1-\mathrm{O} 18-\mathrm{Se} 3$ & $135.5(6)$ & $\mathrm{U} 1-\mathrm{O} 11-\mathrm{Se} 3$ & $124.9(11)$ \\
\hline $\mathrm{U} 2-\mathrm{O} 6-\mathrm{Se} 1$ & $140.2(7)$ & $\mathrm{U} 2-\mathrm{O} 15-\mathrm{Se} 1$ & 137.0 \\
\hline $\mathrm{U} 2-\mathrm{O} 1-\mathrm{Se} 2$ & $133.5(6)$ & $\mathrm{U} 2-\mathrm{O} 6-\mathrm{Se} 2$ & $139.2(11)$ \\
\hline $\mathrm{U} 2-\mathrm{O} 3-\mathrm{Se} 2$ & $133.5(6)$ & $\left\langle\mathrm{U}-\mathrm{O}_{\mathrm{br}}-\mathrm{Se}\right\rangle$ & 137.6 \\
\hline $\mathrm{U} 2-\mathrm{O} 13-\mathrm{Se} 3$ & $134.0(6)$ & & \\
\hline
\end{tabular}

the layer plane. It might be assumed that the lower the average U-O-T angle, the higher the degree of the layer distortion. However, Table 2 and Fig. 11 show that the average value of the bridging angles for the most flat layers (IV) is less than the average value for the most distorted ones (VII). However, the smallest angle in the structure of VII [124.9(11) Å] matches the "wave's crest", while the biggest angle (157.2(13) $\AA$ ) stretches along the "wave's wall" (Fig. 12). The same observation could be also attributed, for instance, to the structure of II, where the similar pair of angles [128.7(4) and 143.3(4) Å] arranged in the similar way. Thus, the local distribution of the U-O-Se links supports the suggestion that the lower $\mathrm{U}-\mathrm{O}_{\mathrm{br}}-\mathrm{T}$ angles correspond to the direction of the higher layer undulation. Another point is that the average angles arranged in the middle part of the interval even for highly distorted layers, which could be explained by the tendency of the layer to flatten itself at least partially.

\section{Conclusion}

In this paper, we have reported seven new uranyl oxysalts with selenium and organic amines. The observed topologies of the structural units of new compounds have been investigated using graphs, and the special approach based upon construction of orientation matrices has been applied to distinguish different geometrical isomers of uranyl selenates and selenite-selenates with the same structural topologies. The statistical analysis of the $\mathrm{U}-\mathrm{O}_{\mathrm{br}}-\mathrm{Se}$ bond angles in selenium polyhedra in the crystal structures showed the possibility for the specification of the undulation of crystal complexes. Further analysis of the data accumulated for uranyl oxysalts may 


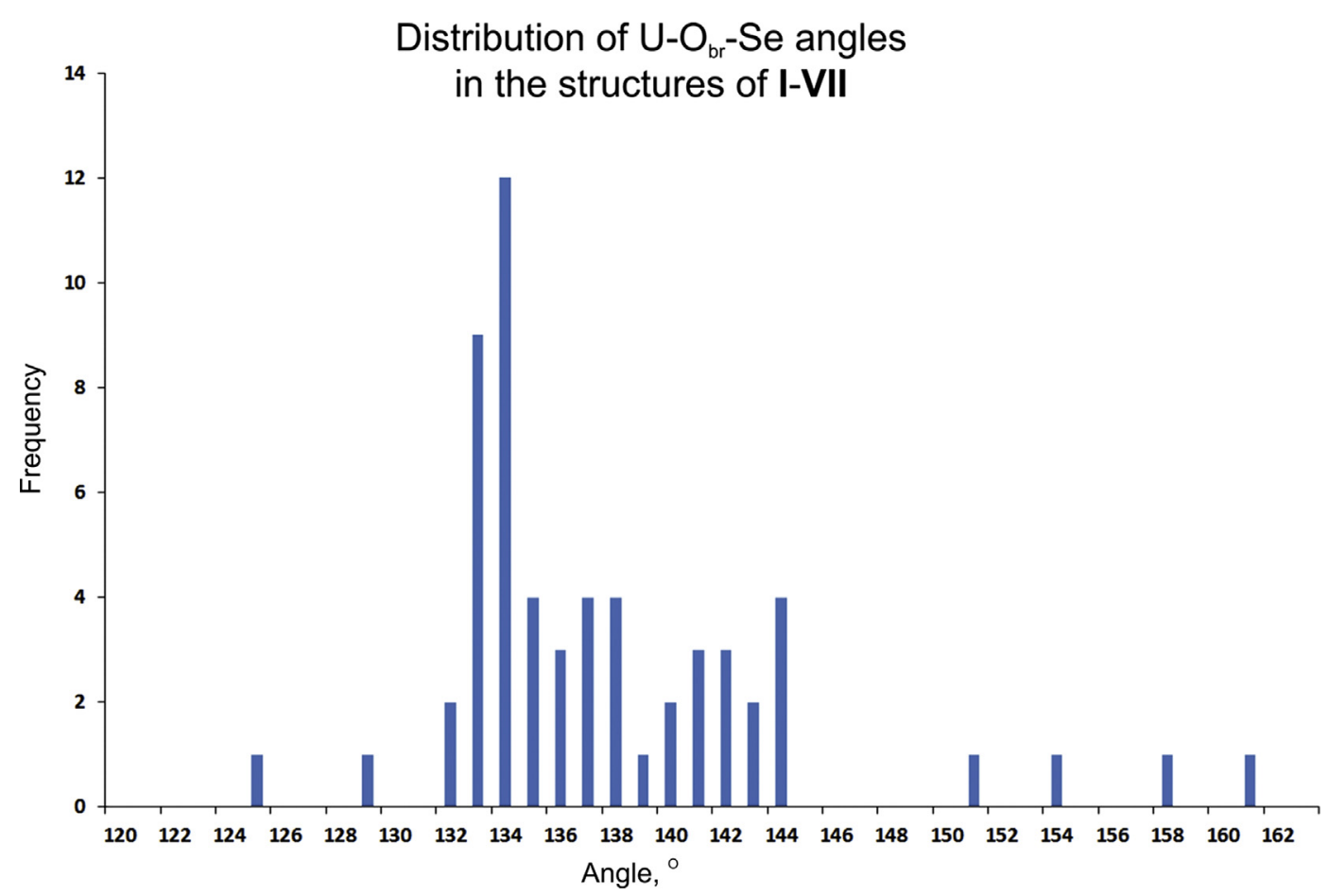

Fig. 11. Distribution of $\mathrm{U}-\mathrm{O}_{\mathrm{br}}-\mathrm{Se}$ angles in the structures of I-VII.

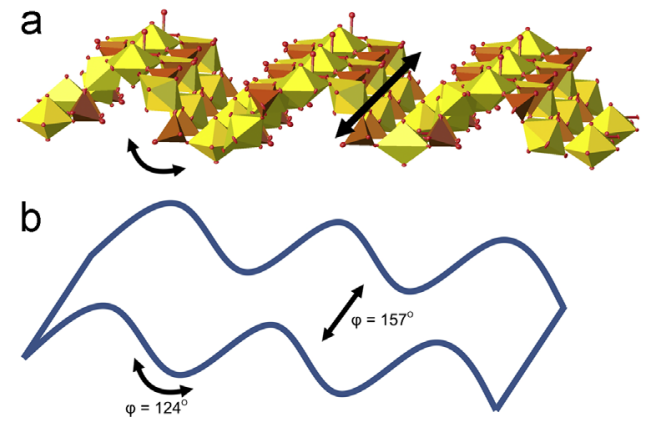

Fig. 12. The smallest angle $(124.9(11) \AA)$ in the structure of VII matches the "wave's crest" while the biggest angle $(157.0(13) \AA)$ stretches along the "wave's wall"; fragment of the structure of VII (a) and its schematic view (b).

provide more details for understanding of how cations of various shape and dimensionality influence topology and geometry of complex inorganic substructures.

\section{Acknowledgments}

This work was supported by St. Petersburg State University (internal grant 3.38.136.2014), President of Russian Federation grant for young scientists (no. MK-1737.2014.5 to VVG) and Russian Foundation for Basic Research (grant 12-05-33097 to VMK). X-ray diffraction studies were carried out in the X-ray Diffraction Centre of St. Petersburg State University.

\section{Appendix A. Supporting information}

Supplementary data associated with this article can be found in the online version at http://dx.doi.org/10.1016/j.jssc.2015.04.040.

\section{References}

[1] S.V. Krivovichev, P.C. Burns, Can. Mineral. 43 (2005) 713-720.

[2] S.V. Krivovichev, P.C. Burns, Can. Mineral. 41 (2003) 707-719.

[3] S.V. Krivovichev, P.C. Burns, Can. Mineral. 40 (2002) 201-209.

[4] G.E. Sigmon, P.C. Burns, J. Am. Chem. Soc. 133 (2011) 9137-9139.

[5] P.C. Burns, C.R. Chim. 13 (2010) 737-746.

[6] G.E. Sigmon, B. Weaver, K.A. Kubatko, P.C. Burns, Inorg. Chem. 48 (2009) 10907-10909.

[7] P.C. Burns, K.A. Kubatko, G.E. Sigmon, B.J. Fryer, J.E. Gagnon, M.R. Antonio, L. Soderholm, Angew. Chem. Int. Ed. 44 (2005) 2135-2139.

[8] J. Ling, M. Ozga, M. Stoffer, P.C. Burns, Dalton Trans. 41 (2012) 7278-7284

[9] J. Ling, J. Qiu, P.C. Burns, Inorg. Chem. 51 (2012) 2403-2408.

[10] P.C. Burns, Mineral. Mag. 75 (2011) 1-25.

[11] J. Ling, J. Qiu, J.E.S. Szymanowski, P.C. Burns, Chem. Eur. J 17 (2011) 2571-2574.

[12] S.V. Krivovichev, V. Kahlenberg, R. Kaindl, E. Mersdorf, I.G. Tananaev, B.F. Myasoedov, Angew. Chem. Int. Ed. 44 (2005) 1134-1136.

[13] S.V. Krivovichev, V. Kahlenberg, I.G. Tananaev, R. Kaindl, E. Mersdorf, B.F. Myasoedov, J. Am. Chem. Soc. 127 (2005) 1072-1073.

[14] E.V. Alekseev, S.V. Krivovichev, W. Depmeier, Angew. Chem. Int. Ed. 47 (2008) $549-551$.

[15] V.V. Gurzhiy, S.V. Krivovichev, . Vestn S.-Peterb. Univ., Ser. : Geol., Geogr. 7 vol. 3 (2008) 33-40.

[17] S.V. Krivovichev, V. Kahlenberg, J. Alloys Compd. 395 (2005) 41-47.

[18] S.V. Krivovichev, V. Kahlenberg, J. Alloys Compd. 389 (2005) 55-60.

[19] S.V. Krivovichev, V. Kahlenberg, Z. Anorg. Allg. Chem. 630 (2004) 2736-2742.

[20] L.J. Jouffret, E.M. Wylie, P.C. Burns, Z. Anorg. Allg. Chem. 638 (2012) $1796-1803$.

[21] V.V. Gurzhiy, P.A. Mikhailenko, S.V. Krivovichev, I.G. Tananaev, B.F. Myasoedov, Russ. J. Gen. Chem. 82 (2012) 23-26.

[22] V.M. Kovrugin, V.V. Gurzhiy, S.V. Krivovichev, I.G. Tananaev, B.F. Myasoedov, Mendeleev Commun. 22 (2012) 11-12.

[23] S.V. Krivovichev, V.V. Gurzhiy, I.G. Tananaev, B.F. Myasoedov, Z. Kristallogr. 224 (2009) 316-324.

[24] S.V. Krivovichev, V.V. Gurzhiy, I.G. Tananaev, B.F. Myasoedov, Russ. J. Gen. Chem. 79 (2009) 2723-2730.

[25] G.M. Sheldrick, SADABS, Univ. Gottingen, Germany, 2004.

[26] Stoe \& Cie, (Darmstadt, Germany): Stoe \& Cie GmbH, 2005.

[27] A. Altomare, G. Cascarano, C. Giacovazzo, A. Guagliardi, M.C. Burla, G. Polidori, M. Camalli, J. Appl. Crystallogr. 27 (1994) 435.

[28] G.M. Sheldrick, Acta Crystallogr. A 64 (2008) 112-122.

[29] O.V. Dolomanov, L.J. Bourhis, R.J. Gildea, J.A.K. Howard, H. Puschmann, Appl. Crystallogr. 42 (2009) 339-341.

[30] M. Koskenlinna, I. Mutikainen, T. Leskela, M. Leskela, Acta Chem. Scand. 51 (1997) 264-269.

[31] P.M. Almond, T.E. Albrecht-Schmitt, Inorg. Chem. 41 (2002) 1177-1183. 
[32] S.V. Krivovichev, I.G. Tananaev, V. Kahlenberg, B.F. Myasoedov, Dokl. Phys. Chem. 403 (2005) 124-127.

[33] S.V. Krivovichev, I.G. Tananaev, V. Kahlenberg, B.F. Myasoedov, Radiochemistry 48 (2006) 217-222.

[34] S.V. Krivovichev, Radiochemistry 46 (2004) 434-437.

[35] S.V. Krivovichev, V. Kahlenberg, E.Yu. Avdontseva, E. Mersdorf, R. Kaindl, Eur. J. Inorg. Chem. 2005 (2005) 1653-1656.

[36] S.V. Krivovichev, Crystallogr. Rev. 10 (2004) 185-232.

[37] S.V. Krivovichev, Structural Crystallography of Inorganic Oxysalts, Oxford University Press, Oxford, 2008.

[38] S.V. Krivovichev, Eur. J. Inorg. Chem. 2010 (2010) 2594-3437.

[39] V.V. Tabachenko, V.N. Serezhkin, L.B. Serezhkina, L.M. Kovba, Zh. Neorg. Khim. 5 (1979) 1563-1568.

[40] Yu.N. Mikhailov, Yu.E. Gorbunova, E.A. Demchenko, L.B. Serezhkina, V.N. Serezhkin, Zh. Neorg. Khim. 45 (2000) 1711-1713.

[41] A.J. Norquist, P.M. Thomas, M.B. Doran, D. O’Hare, Chem. Mater. 14 (2002) 5179-5184.

[42] A.J. Norquist, M.B. Doran, P.M. Thomas, D. O'Hare, Dalton Trans. 2003 (2003) $1168-1175$.

[43] A.J. Norquist, M.B. Doran, Solid State Sci. 5 (2003) 1149-1158.

[44] P.M. Thomas, A.J. Norquist, M.B. Doran, J. Mater. Chem. 13 (2003) 88-92.

[45] C.L. Stuart, M.B. Doran, A.J. Norquist, D. O'Hare, Acta Crystallogr. E 59 (2003) $\mathrm{m} 446-\mathrm{m} 448$.

[46] R. Mercier, T.M. Pham, P. Colomban, Solid State Ionics 15 (1985) 113-126.
[47] T.M. Gesing, C.H. Rüscher, Z. Anorg. Chem. 626 (2000) 1414-1420.

[48] S.V. Krivovichev, V. Kahlenberg, Z. Naturforsch. 60b (2005) 538-542.

[49] S.V. Krivovichev, V. Kahlenberg, Z. Anorg. Chem 631 (2005) 2352-2357.

[50] V.M. Kovrugin, V.V. Gurzhiy, S.V. Krivovichev, Struct. Chem. 23 (2012) 2003-2017.

[51] M.B. Doran, A.J. Norquist, D. O'Hare, Inorg. Chem. 42 (2003) 6989-6995.

[52] S.V. Krivovichev, V.V. Gurzhii, I.G. Tananaev, B.F. Myasoedov, Dokl. Phys. Chem. 409 (2006) 228-232.

[53] V.V. Gurzhiy, O.S. Tyumentseva, S.V. Krivovichev, I.G. Tananaev, B.F. Myasoedov, Radiochemistry 54 (2012) 43-47.

[54] Y.u.N. Mikhailov, Y.u.E. Gorbunova, L.B. Serezhkina, V.N. Serezhkin, Zh. Neorg. Khim. 42 (1997) 734-738.

[55] S.V. Krivovichev, P.C. Burns, Z. Kristallogr. 218 (2003) 725-732.

[56] S.V. Krivovichev, I.G. Tananaev, B.F. Myasoedov, Radiochemistry 48 (2006) $552-560$.

[57] S.V. Krivovichev, V. Kahlenberg, Z. Anorg. Allg. Chem. 631 (2005) 739-744.

[58] S.V. Krivovichev, P.C. Burns, Z. Kristallogr. 218 (2003) 683-690.

[59] S.V. Krivovichev, P.C. Burns, I.G. Tananaev, Structural Chemistry of Inorganic Actinide Compounds, Elsevier, The Netherlands (2007) 494.

[60] V.V. Gurzhiy, D.V. Tyshchenko, S.V. Krivovichev, I.G. Tananaev, Z. Kristallogr. 229 (2014) 368-377. 